\title{
KOHERENSI PERTANYAAN GURU PADA PEMBELAJARAN
}

\author{
Ribut Wahyu Eriyanti \\ Fakultas Keguruan dan Ilmu Pendidikan \\ Universitas Muhammadiyah Malang \\ ributwahyueriyanti@yahoo.com
}

\begin{abstract}
Abstrak: Penelitian ini mendeskripsikan retorika bertanya guru dalam pembelajaran ditinjau dari (1) koherensi pertanyaan guru dalam pembelajaran, (2) pemakaian penanda kohesi pertanyaan guru dalam pembelajaran, dan (3) respon siswa terhadap pertanyaan guru dalam pembelajaran. Penelitian ini menggunakan pendekatan kualitatif induktif dengan perspektif fenomenologis yang memadukan teori retorika, pragmatik, dan wacana secara integratif. Data penelitian ini berupa retorika pertanyaan guru dalam pembelajaran. Hasil penelitian menunjukkan (1) koherensi pertanyaan guru pada pembelajaran dinyatakan secara eksplisit dan implisit. Koherensi eksplisit dinyatakan menggunakan penanda penghubung formal (penanda kohesi) pengulangan (reduplikasi), substitusi, penanda hubung, koreferensi, dan hubungan leksikal; sedangkan koherensi implisit pertanyaan guru dapat dipahami melalui inferensi, kesamaan pengetahuan dunia penutur (guru) dan mitra tutur (siswa), melalui penafsiran lokal (kontekstual), dan implikatur. (2) Penanda kohesi yang digunakan guru meliputi (a) pengulangan utuh dan sebagian, (b) substitusi: pronomina dan demonstratif, (c) hiponimi, dan (d) hubungan leksikal. (3) Berdasarkan koherensi dan pemakaian penanda kohesi dalam pertanyaan guru tersebut, respon siswa cenderung berupa jawaban singkat.
\end{abstract}

Kata kunci: koherensi, pertanyaan guru, pembelajaran

\begin{abstract}
This study described the teachers' questioning rhetoric the teaching and learning process in terms of (1) teachers' questioning coherence, (2) the use of a cohesion marker of teachers' questions, and (3) the students' response to the teacher's questions. This study used a qualitative approach with the inductive phenomenological perspective that combines the theory of rhetoric, pragmatic and discourse. The research data were in the form of teachers' questioning rhetoric. The results showed that (1) teachers' questioning coherence was stated explicitly and implicitly. The explicit coherence was stated using a marker cohesion, repetition (reduplication), substitution, marker-circuited, co-reference and lexical relations; while the implicit coherence of the teacher's questions could be understood through inference, the similarity of teachers' knowledge and the listeners (students), through local interpretation (contextual), and implicatures. (2) Cohesion markers used by the teachers included (a) complete and partial repetition, (b) demonstrative pronoun substitution, (c) hyponymy, and (d) lexical relation. (3) Based on the coherence and the use of cohesion markers in the teachers' questions, students' responses tended to be short answers.
\end{abstract}

Keywords: coherence, teachers' questions, learning

\section{PENDAHULUAN}

Perkembangan mutakhir pelaksanaan pembelajaran berdasarkan amanat Kurikulum 2013 adalah diterapkannya Pendekatan Saintifik. Pendekatan tersebut diterapkan pada semua mata pelajaran untuk semua jenis dan jenjang pendidikan. Pendekatan saintifik dalam pembelajaran didasarkan pada pelaksanaan metode ilmiah dalam penemuan ilmu pengetahuan. Berlandaskan metode ilmiah tersebut, pendekatan saintifik lebih mengedepankan penalaran induktif (inductive reasoning) dibandingkan dengan penalaran deduktif (deductive reasoning). Dengan strategi induktif, sintaks pembelajaran dengan pendekatan saintifik meliputi kegiatan: mengamati-menanya-mengumpulkan informasi/mencoba-mengasosiasi/menalarmengomunikasikan. Dengan demikian, guru dituntut selalu bertanya dan mengondisikan siswa untuk berani dan mampu bertanya.

Dari hasil penelitian diketahui bahwa pembelajaran berbasis pendekatan ilmiah lebih efektif dibandingkan dengan pembelajaran tradisional. Hasil penelitian tersebut membuktikan bahwa pada pembelajaran tradisional, retensi informasi dari guru sebesar 10 persen setelah 15 menit dan perolehan 
pemahaman kontekstual sebesar 25 persen. Pada pembelajaran berbasis pendekatan ilmiah, retensi informasi dari guru sebesar lebih dari 90 persen setelah dua hari dan perolehan pemahaman kontekstual sebesar 50-70 persen (Kementrian Pendidikan dan Kebudayaan, 2013).

Bertolak dari pentingnya pertanyaan dalam pembelajaran tersebut, perlu dilakukan penelitian secara lebih mendalam mengenai retorika bertanya guru dalam pembelajaran, khususnya tentang koherensi pertanyaan guru pada pembelajaran.

Sebagaimana dikemukakan pada penelitian sebelumnya bahwa penelitian tentang retorika dalam bahasa guru pada pembelajaran pernah dilakukan, tetapi difokuskan pada jenis-jenis pertanyaan dan fungsinya dalam pembelajaran (Eriyanti, 2014). Penelitian sejenis juga pernah dilakukan, yang difokuskan pada konstruksi ideologi dalam bahasa guru pada pembelajaran (Eriyanti, 2014). Penelitian ini dilaksanakan untuk melengkapi hasil-hasil penelitian tersebut, sehingga diharapkan dapat diperoleh pemahaman secara lebih lengkap dan mendalam tentang retorika bahasa guru dalam pembelajaran.

Retorika merupakan kemampuan berkomunikasi secara efektif dengan menggunakan bahasa sebagai medianya (Hendrikus, 1991: 6). Komunikasi dapat berlangsung efektif bila tidak ada kesalahpahaman di antara komunikator dan audience (Syafi'ie, 1998). Oleh karena itu, komunikator memilih bahasa yang mampu menyampaikan pesannya dengan tepat. Sebaliknya, audience memilih kode-kode bahasa yang tepat pula untuk memahami pesan yang disampaikan komunikator. Kegiatan memilih bahasa, merupakan ciri utama retorika. Hal lain yang juga merupakan ciri utama retorika adalah domain etik.

Keraf (1985: 18-19) mengemukakan unsurunsur retorika meliputi: (1) struktur gagasan (proposisi, argumen, penalaran), struktur paparan (kohesi dan koherensi), dan sruktur bahasa (diksi, kalimat, dan gaya bahasa). Ketiga unsur pokok retorik tersebut pada dasarnya merupakan perwujudan prinsip dasar dalam retorika modern, yang meliputi: (1) penguasaan secara aktif sejumlah kosakata, (2) penguasaan secara aktif kaidah-kaidah ketatabahasaan, (3) penguasaan gaya bahasa, (4) penguasaan penalaran yang logis dan urut, dan (5) penguasaan teknik pemaparan baik lisan maupun tulis.

Bertolak dari unsur-unsur pokok retorika, penelitian ini difokuskan pada retorika struktur paparan, yang meliputi kohesi dan koherensi dalam struktur paparan. Hal ini dimaksudkan untuk melengkapi hasil penelitian sebelumnya (Eriyanti, 2014). Penelitian ini difokuskan pada retorika struktur bahasa pertanyaan guru dalam pembelajaran, yang meliputi: (1) koherensi pertanyaan guru pada pembelajaran, (2) pemakaian penanda kohesi dalam pertanyaan guru, dan (3) respon siswa terhadap pertanyaan guru.

Leech (1983: 15) mengemukakan bahwa penggunaan istilah retorika biasanya mengacu pada studi penggunaan bahasa secara efektif dalam berkomunikasi. Dalam prinsip pragmatik, Leech menggunakan istilah retorika sebagai seperangkat prinsip percakapan yang dikaitkan dengan fungsifungsinya. Dalam hal ini, Leech membedakan Retorika Interpersonal dan Textual. Masing-masing jenis retorika terdiri atas seperangkat prinsip-prinsip percakapan, yakni prinsip kerjasama (cooperative principle) dan prinsip sopan santun (politeness principle) dalam retorika interpersonal dan prinsip prosesibilitas (processibility principle) dan prinsip kejelasan (clarity principle) dalam retorika textual.

Prinsip-prinsip ini terdiri atas beberapa maksim sebagaimana dalam terminologi Grice. Teori Grice tentang conversasional implikatur secara mendasar berasal dari prinsip umum percakapan ditambah sejumlah konvensi atau maksim yang pada umumnya dipakai seorang pembicara. Prinsip percakapan umum tersebut kemudian disebut "cooperative principle" yang maksudnya "berikan bantuanmu seperti yang dibutuhkan pada tingkat di mana hal itu terjadi, sesuai dengan tujuan atau arah pertukaran pembicaraan di mana kamu terlibat di dalamnya" (Marcelino dalam Mujianto, 1998: 62).

Dalam prinsip kerja sama terdapat empat maksim yang pada dasarnya keempat prinsip umum tersebut memberikan arah kepada orang yang sedang bertutur kata tentang apa yang harus dikerjakan agar ia memperoleh hasil yang maksimal, efiisien, rasional, dan kooperatif. Oleh karena itu, ia harus berbicara dengan jujur, relevan, jelas, dan mau memberi informasi secukupnya yang diperlukan (Wahab, 1991: 140).

Keempat maksim dalam prinsip kerjasama Grice meliputi: (1) maksim kuantitas, yang mencakup (a) berikan bantuanmu seinformatif yang dibutuhkan dan (b) jangan memberikan bantuan lebih informatif daripada yang dibutuhkan. (2) Maksim kualitas, yang mencakup (a) jangan mengatakan sesuatu apabila kamu yakin hal itu salah dan (b) jangan berkata apabila kamu kekurangan bukti yang memadai. (3) Maksim hubungan, yang mengarah 
pada berikan bantuan yang relevan. (4) Maksim cara, yakni mencakup (a) hindari ketidakjelasan pernyataan, (b) hindari ambiguitas, (c) jangan bertetele (singkatlah), dan (d) teraturlah (Leech, 1983: 8; Brown \& Yule, 1983: 32).

Pembelajaran merupakan proses interaksi antara peserta didik dengan pendidik, peserta didik dengan peserta didik yang lain, serta dengan sumber belajar lain untuk mencapai tujuan pendidikan. Batasan pengertian pembelajaran tersebut menunjukkan bahwa pembelajaran dilaksanakan bukan untuk menyajikan pengetahuan kepada peserta didik, melainkan menciptakan kondisi dan memfasilitasi peserta didik untuk dapat belajar melalui berbagai sumber belajar yang ada.

Peraturan Menteri Pendidikan dan Kebudayaan Nomor 65 Tahun 2013 (Standar Proses) menegaskan bahwa pengembangan keterampilan peserta didik dilaksanakan dengan kegiatan mengamati, menanya, mencoba, menalar, menyaji, dan mencipta (pendekatan Saintifik). Dengan pendekatan tersebut, guru dituntut selalu bertanya (banyak mengajukan pertanyaan) kepada siswa. Bahkan ditegaskan pula bahwa guru harus menciptakan kondisi siswa untuk mau dan mampu bertanya. Dengan demikian, dapat diketahui bahwa guru dituntut memiliki kemampuan bertanya.

Kegiatan bertanya dalam pembelajaran dilaksanakan bukan hanya pada kegiatan inti pembelajaran, melainkan sejak kegiatan pendahuluan. Pada bagian pendahuluan, kegiatan bertanya diutamakan untuk membantu siswa mengaitkan pengetahuan sebelumnya dengan materi yang akan dipelajari (Permendikbud Nomor 65, 2013). Pada bagian inti pembelajaran, kegiatan bertanya diperlukan terutama untuk mengembangkan keterampilan peserta didik. Hal itu sesuai dengan pernyataan dalam Standar Proses sebagai berikut, "Keterampilan diperoleh melalui kegiatan mengamati, menanya, mencoba, menalar, menyaji, dan mencipta.” Dengan demikian jelas bahwa dengan diterapkannya Kurikulum 2013, pembelajaran akan dipenuhi dengan kegiatan bertanya, baik oleh guru maupun oleh siswa.

Pentingnya pertanyaan guru dalam pembelajaran ditegaskan pula dalam Modul Pelatihan implementasi Kurikulum 2013 (Kementrian Pendidikan dan Kebudayaan, 2013), "Guru yang efektif mampu menginspirasi peserta didik untuk meningkatkan dan mengembangkan ranah sikap, keterampilan, dan pengetahuannya. Pada saat guru bertanya, pada saat itu pula dia membimbing atau memandu peserta didiknya belajar dengan baik. Ketika guru menjawab pertanyaan peserta didiknya, ketika itu pula dia mendorong asuhannya itu untuk menjadi penyimak dan pembelajar yang baik.” Mengingat pentingnya pertanyaan dalam pembelajaran, penelitian ini difokuskan pada retorika bertanya guru dalam pembelajaran, khususnya masalah koherensi pertanyaan guru secara lisan.

Kohesi merupakan hubungan perkaitan antarproposisi yang dinyatakan secara eksplisit oleh unsur-unsur gramatikal dan semantik dalam kalimatkalimat yang membentuk wacana (Alwi, dkk, 2003: 427). Widdowson (1979) menyatakan bahwa kohesi itu sebagai hubungan yang ditandai secara lahir (hubungan yang tampak pada bentuk). Lebih jelas dari pendapat Widdowson, Samsuri (dalam Oka dan Basuki, 1990) menyatakan bahwa kohesi sebagai hubungan yang ditandai oleh penanda-penanda lahir, yakni penanda yang menghubungkan apa yang dinyatakan dengan apa yang dinyatakan sebelumnya dalam wacana yang bersangkutan.

Halliday dan Hasan (1976: 15) membagi penanda kohesi menjadi lima kategori, yakni referensi, elips, konjungsi, substitusi, dan leksikal. Oleh Canale (1981: 34) disederhanakan menjadi dua kategori, yakni kohesi gramatikal, yang meliputi referensi, substitusi, dan elips. Kedua adalah kohesi leksikal, yang meliputi konjungsi dan leksikal.

Jika kohesi merupkan keruntutan kalimat-kalimat dan hubungan struktural antarkalimat dalam wacana, koherensi merupakan hubungan semantis antarkalimat atau antarbagian wacana, yakni hubungan yang serasi antara proposisi-proposisi atau antarmakna satu dengan yang lain. Dengan demikian, koherensi tidak selalu dinyatakan dengan penanda kohesi.

Ada berbagai cara yang dapat dilakukan untuk menentukan koherensi, yakni inferensi, pengetahuan tentang dunia, prinsip analogi, penafsiran lokal, implikatur, dan praanggapan (Ibrahim, 2001: 45). Pertama, inferensi merupakan proses pemahaman terhadap makna tuturan dengan cara menyimpulkan informasi berdasarkan tuturan yang dihadapinya. Kedua, pengetahuan tentang dunia adalah pengetahuan mengenai isi tuturan yang berkenaan dengan topik wacana. Ketiga, prinsip analogi, yang diformulasikan dengan menerapkan pengalamanpengalaman yang mirip dan yang sudah diketahui untuk memahami wacana baru. Keempat, penafsiran lokal, yaitu upaya penentuan makna tuturan berdasarkan konteks tempat terjadinya komunikasi. Kelima, implikatur adalah informasi implisit yang dapat ditentukan berdasarkan suatu tuturan. Kaitan tersebut tidak dinyatakan secara nyata dalam percakapan. 


\section{METODE}

Penelitian ini menggunakan pendekatan kualitatif induktif dengan perspektif fenomenologis. Oleh sebab itu, penelitian ini dilaksanakan dengan didasarkan pada paradigma naturalistik-fenomenologis (Jumadi, 2005: 45). Berdasarkan paradigma tersebut, upaya mengonstruksi makna dan fungsi pertanyaan guru yang terepresentasikan dalam retorika guru pada pembelajaran dilakukan dalam keutuhan konteks penggunaan bahasa.

Data penelitian ini berupa retorika pertanyaan guru dalam pembelajaran, yang meliputi (1) koherensi pertanyaan yang digunakan guru dalam pembelajaran; (2) pemakaian penanda kohesi dalam pertanyaan guru pada pembelajaran, dan (3) respon siswa terhadap pertanyaan guru dalam pembelajaran. Sumber data penelitian ini adalah tuturan guru dalam pembelajaran di satu SMP Negeri di Kota Malang dan satu SMP swasta di Kota Malang, baik pada matapelajaran Bahasa Indonesia maupun matapelajaran lain yang menggunakan bahasa Indonesia sebagai bahasa pengantarnya.

Pengumpulan data penelitian ini dilakukan melalui metode observasi pembelajaran yang telah direkam ke dalam bentuk video, sehingga diperoleh data tuturan secara lengkap. Data yang terkumpul dianalisis secara kualitatif fenomenologis dengan memanfaatkan teori retorika, teori pragmatik, dan analisis wacana.

Berdasarkan kerangka kerja tersebut, analisis data penelitian ini dilakukan menggunakan teknikteknik pemahaman secara mendalam dengan didasarkan pada prinsip-prinsip tindak tutur, analisis dialektis atau bolak-balik sesuai dengan keperluan (Hymes, 1974). Analisis data dilakukan selama dan setelah pengumpulan data dengan mengikuti alur analisis yang dikemukakan oleh Miles \& Huberman (Moleong, 2005: 45). Berdasarkan model Miles \& Huberman tersebut, analisis data dilakukan secara interaktif yang terdiri atas tiga tahap, yakni (1) reduksi data, (2) deskripsi data, dan (3) verifikasi serta penarikan kesimpulan.

\section{HASIL DAN PEMBAHASAN}

\section{Koherensi Pertanyaan Guru pada Pembelajaran}

Koherensi merupakan hubungan semantis antarkalimat atau antarbagian wacana, yakni hubungan yang serasi antara proposisi-proposisi atau antarmakna satu dengan yang lain. Bedasarkan makna koherensi tersebut, koherensi pertanyaan guru pada pembelajaran dimaknai sebagai hubungan semantis antara proposisi-proposisi pertanyaan guru pada konteks pembelajaran. Hal itu berarti bahwa koherensi pertanyaan guru tidak hanya dikenali melalui bentuk formal bahasa yang digunakan guru dalam bertanya kepada siswa, melainkan juga dari segi semantis tuturan guru dalam bertanya kepada siswa saat pembelajaran.

Berdasarkan batasan tersebut dan juga datadata yang dikumpulkan, ditemukan bahwa pertanyaan-pertanyaan yang disampaikan kepada siswa selama pembelajaran menunjukkan koherensi antarproposisi-proposisi dalam wacana pembelajaran. Koherensi pertanyaan guru tersebut dapat dikenali secara formal dalam bentuk pemakaian penanda kohesi maupun secara implisit. Berdasarkan kedua jenis koherensi tersebut dan sesuai dengan rumusan masalah penelitian yang ditetapkan, paparan hasil penelitian ini dikelompokkan menjadi dua kategori. Kategori pertama yang dipaparkan adalah koherensi pertanyaan guru yang dinyatakan secara eksplisit melalui pemakaian penanda kohesi secara formal dan koherensi yang dinyatakan secara implisit dalam bentuk hubungan semantis (makna bahasa yang dituturankan guru).

\section{Koherensi Pertanyaan Guru yang Dinyatakan Secara Eksplisit}

Koherensi pertanyaan guru yang dinyatakan secara eksplisit adalah keserasian hubungan proposisiproposisi pertanyaan guru yang dituturkan dengan menggunakan penanda hubung secara formal dalam bentuk pemakaian bahasa, baik melalui bentuk pengulangan secara utuh, pemakaian kata ganti (substitusi), pemakaian penanda hubung, maupun hubungan leksikal. Hal itu ditemukan dalam bentuk data-data sebagai berikut.

(1) Guru : "Saya minta tolong "cowok" untuk mengambil buku paket di meja saya."

Siswa: (salah seorang siswa beranjak dan berjalan menuju ke meja guru)

Guru : “ Sambil menanti teman yang lagi mengambil buku paket, kalau saya menanyakan tentang puisi kepada anakanak, rata-rata puisi itu sulit. Puisi itu sulit dibuat, dah. Perhatikan! Memang puisi itu berangkat dari sebuah bakat, benar kan?

(2) Siswa : "Citraan? Citraan itu apa?"

Guru : "Belum disampaikan? Baiklah, jenis- 
jenis citraan yaitu citraan penglihatan, citraan pendengaran, citraan penciuman, citraan perabaan, citraan perasaan, citraan pengecapan, citraan gerak. Nama dari citraan penglihatan adalah?

Data (1) pertanyaan guru yang disampaikan kepada siswa, "Sambil menanti teman yang lagi mengambil buku paket, kalau saya menanyakan tentang puisi kepada anak-anak, rata-rata puisi itu sulit. Puisi itu sulit dibuat, dah. Perhatikan! Memang puisi itu berangkat dari sebuah bakat, benar kan?” Pada data tersebut, hubungan proposisi-proposisi pertanyaan guru dinyatakan secara eksplisit menggunakan bentuk pengulangan secara utuh, yaitu pengulangan puisi itu. Demikian juga dengan data (2), pengulangan yang digunakan untuk menghubungkan proposisi sebelum dan sesudahnya adalah citraan.

Selain menggunakan pengulangan, koherensi pertanyaan guru yang dinyatakan secara eksplisit, ditandai dengan pemakaian kata pengganti (substitusi). Hal itu terdapat pada data berikut.

(3) Guru : "Sudah dibaca? Kira- kira objeknya di mana ya? Objeknya di Mana ya? Di Kota Metropolitankah, di pantaikah, atau di sebuah desa?

Siswa : "Ya, di sebuah desa."

Guru : “ O... Di sebuah desa. Jadi maksud pengarang membuat itu, untuk apa gitu ya? Apakah Cuma sekedar membedakan pemandangan di kota dengan di desa? Apakah tujuannya itu untuk mengagumi keindahan alam ciptaan Allah? Dah, apakah seperti itu? Mana mengagumi? Coba kalian cari barisan mana yang menunjukkan kekaguman? Coba baca syairnya. Mana yang menunjukkan kekaguman? Kalau orang kampung itu pasti ada yang mempesona toh? Kalau kalian ke kampung, pasti ada sesuatu yang menarik. Yang menarik apa?”

Pada data (3), tuturan pertanyaan guru menunjukkan adanya hubungan yang harmonis (koherensi) antarproposisi pertanyaan guru. Hal itu ditunjukkan dengan pemakaian penanda kohesi substitusi, yaitu penggantian bentuk yang disebutkan sebelumnya dengan bentuk lain yang disebutkan kemudian dengan menggunakan kata "itu". Kata itu pada petanyaan "Jadi maksud pengarang membuat $i t u$, untuk apa gitu ya? menunjuk pada pertanyaan sebelumnya, yaitu “Objeknya di mana ya?” Di Kota Metropolitankah, di pantaikah, atau di sebuah desa?

Pemakaian penanda kohesi substitusi juga terdapat pada pertanyaan berikut.

(4) Guru : "Ya, sekarang kita akan membahas tentang bakso, apa saja sih yang terdapat di dalam bakso?” (sambil menunjukkan gambar yang ingin muridnya menjawab)

Murid : "Ada piring, mangkok."

Guru : "Terus apa lagi yang ada? (sambil menuju ke bangku murid)."

Murid : "Ada sayur, mie, pentol, gorengan, saos, sambel, kuah.”

Guru : "Kalau kita lihat dari komposisi makanan ini, tentu saja makanan ini enak, (sambil menunjukkan gambarnya). Terus menurut kalian rasanya bagaimana kira-kira?" (berjalan menuju bangku siswa)

Pada data (4), pertanyaan guru menunjukkan adanya hubungan yang harmonis (koherensi) antarproposisi pertanyaan guru. Hal itu ditunjukkan dengan pemakaian penanda kohesi substitusi, yaitu penggantian bentuk yang disebutkan sebelumnya dengan bentuk lain yang disebutkan kemudian dengan menggunakan bentuk pronomina "-nya” pada kata rasanya. Klitik nya pada kata rasanya menunjuk pada referen yang sama dengan rasa makanan, sehingga bermakna rasa makanan.

Koherensi juga dapat diciptakan dengan menggunakan penanda kohesi berbentuk hubungan leksikal, yakni hiponimi. Hal itu terdapat pada tuturan pertanyaan guru sebagai berikut.

(5) Guru : "Betul? sudah selesai?" (sambil menunjuk ke murid)

Tapi yang masih lapar kan banyak, termasuk saya. Nah pengelompokkan zat adiktif, itu berdasarkan sumbernya itu ada dua. Yang pertama alami dan yang kedua sintetik atau buatan (sambil berhitung menggunakan jari). Yang alami, alami, alami, iya to? Kemudian kalau sintetis berasal dari bahan kimia atau buatan pabrik. Kalau kita lihat seperti ini, hampir semuanya buatan pabrik (sambil menunjuk gambar). Berdasarkan fungsinya zat aditif ada 6. Pertama pewarna, kedua pemanis, pengawet, penyedap rasa, anti oksida, dan penambah nutrisi. Oke kita bahas 
yang pertama dulu mengenai pewarna. Tujuan pemberian warna yang pertama, memberikan warna yang menarik, sehingga merangsang selera untuk makan. Coba jajanan pasar, atau yang ada di gambar ini (sambil menunjuk gambar).

Orang ketika melihat gambarnya saja sudah menarik, menarik sekali padahal kalau kita melihat ini dari mana? Saya cerita sedikit ya, kemarin pas saya lagi ngelesi, di rumahnya adik saya situ ternyata saya disuguhkan kue pelangi. Tahu kue pelangi?” (sambil melihat ke arah murid)

Murid : "Tahu"

Guru : "Seumur-umur saya belum pernah makan itu, baru ini, saya memang biasa kalau ngelesi, saya biasa melaparkan diri, biar berharap kita dapat makanan.

Murid : (Tertawa) "Iya”

Guru : "Gak apa-apa boleh, kemudian yang ingin saya sampaikan adalah jadi kuenya menjadi menarik sekali, karena apa? Pertama warnanya hijau, kuning, kelabu, ada merah, wes gak tahu, ada berapa lapis (sambil menggerakkan tangan bersusun-susun). Kenapa? Karena ada rasa ketertarikan dari warna, termasuk juga ada beberapa jajanan pasar.

Pada data (5) hubungan antarproposisi dijalin dengan menggunakan penanda kohesi leksikal, berupa hiponimi, yaitu penyebutan kuenya yang merujuk pada makna yang sama dengan kata makanan pada tuturan sebelumnya. Koherensi pertanyaan yang disampaikan guru dengan menggunakan penanda hubung bentuk leksikal berupa hiponimi juga terdapat pada data berikut.

(6) Guru : Di Pasuruan itu ada satu daerah perkebunan. Seluruhnya itu dibuat kebun mangga. Jadi mangga macam apa saja di Pasuruan itu ada. Spesies mangga, mulai dari mangga yang nggak enak sampai enak sekali itu di Pasuruan itu ada. Luas sekali ribuan koleksi, atau ada juga kebun sawit misalnya, atau kebun kelapa. Jadi satu daerahnya itu dipakai untuk kebun koleksi. Jadi, khusus untuk tanaman itu mulai dari yang spesiesnya, itu kan ada bermacam-macam, mungkin agrowisata. Pernah ke agrowisata?

Murid : Pernah.

Guru : Itu dipaki untuk kebun apa?

Murid : Kebun apel.

Guru : Kebun apel. Itu kamu bisa petik sendiri. Apel mulai dari apel spesies apa saja di agrowisata bisa kamu dapat. Itu namanya kebun koleksi. Jadi, supaya apa tujuannya, supaya apa tujuannya?

Pada data (6), koherensi pertanyaan guru ditandai dengan pemakaian bentuk leksikal yang berhubungan, yakni kebun mangga dan agrowisata. Kebun mangga merupakan bagian dari agrowisata.

\section{Koherensi Pertanyaan Guru yang Dinyatakan Secara Implisit}

Koherensi pertanyaan guru yang dinyatakan secara implisit adalah keserasian hubungan proposisiproposisi pertanyaan yang dituturkan guru tanpa ditandai dengan penggunaan penanda hubungan secara formal dalam bentuk pemakaian bahasa, baik melalui bentuk pengulangan secara utuh, pemakaian kata ganti, pemakaian penanda hubung, koreferensi, maupun hubungan leksikal. Koherensi tersebut dapat dikenali melalui pemahaman makna tuturan, baik melalui inferensi, pengetahuan tentang dunia berkaitan dengan topik pembicaraan, analogi, penafsiran lokal, maupun pemahaman implikatur. Hal itu ditemukan dalam bentuk data-data sebagai berikut.

(7) Guru

: “ Bakat yang kita punya, ya toh? Itu harus kita kembangkan, harus dilatih, harus banyak latihan. Sesudah dilatih barulah kita akan bisa membuktikan bahwa menyusun puisi itu tidaklah sulit, apalagi punya bakat. Yang tidak punya bakat saja bisa diasah bakatnya. Ya toh? Mulai dari latihan-latihan. Kalau kita tidak pernah latihan, ya belum tentu semuanya sulit. Adik kecil mau makan sendiri ya harus banyak latihan. Kalau nggak latihan ya nggak bisa makan sendiri. Benar kan?

Siswa : "Benar."

Pertanyaan guru “Benar kan?” pada data tersebut menunjukkan koherensi dengan tuturan sebelumnya. Hal itu dapat dipahami melalui pemahaman implikatur tuturan guru sebelumnya, sehingga pertanyaan yang hanya disampaikan dalam bentuk "Benar kan?" memiliki hubungan yang erat dengan proposisi tuturan sebelumnya. 
Selain memulai pemahaman implikatur, koherensi pertanyaan guru pada pembelajaran dapat dipahami melalui pemahaman pengetahuan dunia penutur dan mitra tutur (guru dan siswa). Hal itu terdapat pada tuturan berikut.

(8) Guru : "Ayo duduk dulu!”

Siswa : "Berdoa mulai. Bismillahirrohmaannirrohim...

Guru : "Assalamualaikum warahmatullahi wabarokatuh.”

Siswa : “ Waalaikum salam warahmatullahi wabarokatuh.”

Guru : "Sudah. Sudah siap semua?”

Siswa : "Belum. Belum.”

Guru : "Sebelum kita mulai, ayo semuanya duduk dulu. Sebelum kita mulai ulangannya kita akan absen dulu.”

Pada data tersebut diketahui bahwa pertanyaan guru, "Sudah siap?" yang disampaikan setelah menyampaikan salam menunjukkan hubungan yang harmonis. Hal itu dapat dipahami melalui pengetahuan dunia yang dipahami bersama antara guru dan siswa, yakni sebelumnya guru dan siswa sudah saling mengetahui bahwa pada hari itu akan dilaksanakan ujian. Meskipun saat itu tidak disampaikan terlebih dulu, siswa telah memahami bahwa yang dimaksud sudah siap adalah sudah siap melaksanakan ujian.

Koherensi pertanyaan guru juga disampaikan melalui hubungan kontekstual, sehingga pemahamannya melalui penafsiran lokal. Hal itu terdapat pada data berikut.

(9) Guru : "Sebelum kita mulai, ayo semuanya duduk dulu. Sebelum kita mulai ulangannya kita akan absen dulu. (Guru memanggil siswa satu persatu). Fahri. Fahri masuk apa tidak?”

\section{Siswa : "Tidak.”}

Pertanyaan guru, "Fahri masuk apa tidak? "pada data tersebut koheren dengan proposisi sebelumnya, yakni pemanggilan nama siswa satu persatu untuk mengecek kehadiran siswa. Pernyataan "masuk" pada pertanyaan tersebut meskipun tidak disampaikan secara lengkap dengan menggunakan bentuk formal "masuk sekolah" dapat dipahami oleh siswa berdasarkan konteksnya, yakni awal pembelajaran. Hal itu bisa juga bermakna meminta siswa yang bernama Fahri untuk mengerjakan tugas yang akan disampaikan guru. Akan tetapi, karena penyampaiannya dalam konteks presensi, maka pertanyaan tersebut bermakna menanyakan apakah Fahri masuk sekolah apa tidak.

\section{Pemakaian Penanda Kohesi dalam Pertanyaan Guru pada Pembelajaran}

Penanda kohesi adalah bentuk formal bahasa yang menandai hubungan antarproposisi pertanyaan guru saat pembelajaran, sehingga tuturan tersebut memiliki hubungan yang harmonis. Sesuai dengan jenis-jenis koherensi eksplisit yang telah dipaparkan pada paparan 4.1.1 ditemukan pemakaian penanda kohesi pada pertanyaan guru saat pembelajaran meliputi: reduplikasi (utuh maupun berubah bunyi), koreferensi, penggunaan hubungan unsur kalimat, dan hubungan leksikal.

\section{Penanda Kohesi Reduplikasi}

Penanda kohesi reduplikasi berupa pengulangan kata atau frasa, baik secara utuh maupun sebagian untuk menunjukkan hubungan antarkalimat dalam sebuah wacana. Berdasarkan batasan tersebut, dalam pertanyaan guru pada pembelajaran ditemukan penggunaan penanda kohesi reduplikasi sebagai berikut.

(10) Guru : "Belum disampaikan? Baiklah. Jenisjenis citraan, yaitu citraan penglihatan, citraan pendengaran, citraan penciuman, citraan perabaan, citraan perasaan, citraan pengecapan, citraan gerak. Citraan penglihatan adalah?”

Siswa : "Indera mata."

Guru : "Nama dari citraan pendengaran adalah?”

Siswa : "Citraan perasaan pakai indera apa ya?

Kalimat-kalimat pertanyaan yang disampaikan guru kepada siswa pada pembelajaran tersebut memiliki hubungan yang sangat erat dengan kalimat (tuturan) yang disampaikan sebelumnya. Hubungan tersebut dinyatakan secara eksplisit melalui pengulangan kata 'citraan'. Dengan pengulangan secara utuh kata tersebut, dapat diketahui bahwa yang dibicarakan dalam wacana tersebut adalah citraan. Kata yang diulang pada fragmen wacana tersebut berposisi sebagai subjek.

\section{Penggunaan Kohesi Reduplikasi Juga terdapat pada Pertanyaan Guru sebagai berikut.}

(11) Guru : "Ya, sekarang kita bahas pertama adalah ...?

Siswa : "Bakso, Pak. 
Guru : "Ya, sekarang kita akan membahas tentang bakso. Apa saja yang terdapat di dalam bakso?

Kalimat-kalimat pembelajaran tersebut saling berkaitan secara harmonis. Hubungan tersebut terjalin secara eksplisit melalui pengulangan kata 'bakso', yang menduduki posisi objek. Penggunaan penanda kohesireduplikasi utuh juga terdapat pada pertanyaan guru sebagai berikut.

(12) Guru : "Kalau kita kaitkan dengan makanan tadi yang saya sebutkan dan yang ada di gambar, yang pertama untuk energi. Yang kedua untuk pertumbuhan atau membentuk sel baru. Coba kita melihat, saya punya anak kecil berumur 6 bulan. Ketika berumur lima bulan, sudah mulai saya menyuapi dengan makanan pendamping untuk membantu pertumbuhan. Alhamdulillah sampai sekarang, setelah saya menyuapinya dua minggu sampai enam mingguan, berat badannya menaik. Itu untuk membantu proses pertumbuhan. Laksika, proses pertumbuhan itu apa?

Siswa: "Terjadinya perbedaan pada fisik anak."

Guru : "Kamu tumbuh apa tidak?”

Siswa : "Tumbuh Pak."

Guru : "Tumbuh dari samping mana?”

Pertanyaan guru, "Laksika, proses pertumbuhan itu apa?” memiliki hubungan yang sangat erat dengan tuturan guru sebelumnya. Hubungan tersebut ditandai secara eksplisit melalui pengulangan kata pertumbuhan secara utuh.

Hubungan yang harmonis antarkalimat dalam pembelajaran tersebut juga ditandai dengan pengulangan sebagian kata pertumbuhan, yakni dengan kata tumbuh. Hal itu terdapat pada pertanyaan guru selanjutnya, yaitu "Kamu tumbuh apa tidak?” Disambung lagi dengan pertanyaan berikutnya dengan pengulangan secara utuh, yakni "Tumbuh dari samping mana?"

Berdasarkan data-data tersebut, disimpulkan bahwa hubungan yang harmonis pertanyaanpertanyaan guru dalam pembelajaran dapat terjalin melalui pengulangan kata, baik secara utuh maupun pengulangan sebagian.

\section{Penanda Kohesi Substitusi" atau "Koreferensi"}

Penanda kohesi koreferensi adalah penanda hubungan berupa penggantian leksikal (substitusi) atau sinonim kata, yang mengacu pada referensi yang sama. Kohesi sering pula diciptakan dengan memakai kata yang maknanya sama sekali berbeda dengan makna kata yang diacunya, akan tetapi kata yang digantikan dan kata penggantinya mengacu pada referen yang sama.

Berdasarkan batasan pengertian tersebut, kohesi koreferensi pertanyaan guru pada pembelajaran ditemukan pada pertanyaan-pertanyaan berikut.

(13) Guru ： Kebun apel. Itu kamu bisa petik sendiri. Apel mulai dari apel spesies apa saja di agrowisata bisa kamu dapat. Itu namanya kebun koleksi. Jadi, supaya apa tujuannya, supaya apa tujuannya?

(14) Guru : Ya, menangkar hewan. Menangkar hewan dengan cara?

Murid : Mengisolasi.

Guru : Seperti apa? Caranya bagaimana?

Murid : Melindungi.

Pada pertanyaan-pertanyaan guru tersebut terdapat kata yang memiliki unsur pronomina-nya. Unsur pronomina-nya tersebut mengacu pada unsur atau kata yang sama, yang telah digunakan pada tuturan sebelumnya, yaitu kebun koleksi dan menangkar hewan. Di samping berbentuk pronomina, hubungan koreferensi juga ditunjukkan melalui penanda penunjuk tempat, seperti yang terdapat pada data berikut.

(15) Guru : Yang pernah dengar pas (word education center) jadi pusat pendidikan hewan, pusat penangkaran hewan khususnya orang hutan. Kalau ke Rejo Sewu di situ tempat kerjanya penangkaran hewan. Kalau kamu ke sana kamu bisa tahu, kalau kamu ke sana ya itu kamu harus steril jadi masuk tempatnya itu kakimu ini masuk ke air dulu alas kakimu di lepas baru kamu bisa masuk ke tempat penangkaran hewan itu. Jadi hewanhewan itu yang biasanya kamu dapatkan di Splindit, ada kan di sana yang jual orang hutan? Monyet-monyet itu kan ada, kalau kamu bawa pulang ke rumah ada Undang-undangnya atau kijang kamu punya di rumah itu kan ada Undang-undangnya, kalau ketemu 
satpol PP atau pihak kota madya kamu didenda ratusan juta.

\section{Siswa : Kalau ular?}

Penggunaan kata di sana pada pertanyaan guru tersebut mengacu pada makna atau referen yang sama dengan kata di Splindit, yang telah digunakan pada kalimat sebelumnya. Hal itu digunakan untuk menunjukkan adanya hubungan yang harmonis antara tuturan sebelumnya dan sesudahnya, sehingga terjadi koherensi yang harmonis.

Pemakaian penanda kohesi koreferensi juga terdapat pada data berikut.

(16) Guru : la iya, telur penyu itu seperti itu. Enak makanya banyak yang ngincer. Jadi kemudian dengan memindahkan hewan langka sama dengan harimau Sumatera. Kalau kamu ke taman safari ya, namanya harimau itu bagus-bagus. Ada yang namanya Heri, ada yang namanya Eta. Jadi diberi nama semuanya. Hasil dari apa itu? Hasil dari penangkaran.

Jadi kalau di sana sudah merasa aman, diambil dikembangbiakkan di tempat lain dengan cara memindahkan hewan langka ke tempat lain yang lebih sesuai. Kemudian dibuatkan Undang-undang perburuan. Tujuannya apa membuat Undang-undang perburuan? Supaya kamu tidak ngawur, ndak liar. Jalak Bali dibuat Undang-undang ya. Kalau sampai ada yang nembak burung jalak Bali, tahu jalak Bali?

Siswa : Tahu.

Pada data tersebut ditemukan pemakaian penanda kohesi berupa kata yang mengacu pada referen yang sama dengan kata yang akan disebutkan sesudahnya, yakni berupa pemakaian kata bantu tanya "apa" yang mengacu pada benda atau nama benda, nama kegiatan. Pemakaian kata bantu tanya sebagai bentuk penanda kohesi pertanyaan guru, juga digunakan kata bantu tanya "siapa, bagaimana, berapa, di mana, kenapa, ke mana". Hal iu terdapat pada data berikut.

(17) Guru : Yang membuat, kalau nggak ada, yang membuat hewan-hewan atau tumbuhan itu menjadi langka atau menjadi habis atau tidak ada sama sekali tinggal cerita itu perbuatannya siapa?
Siswa : Manusia.

(18) Guru : Manusia. Dengan cara bagaimana?

(19) Guru : Kamu mungkin hanya cuma dapat sepuluh kilogram. Itu pun isinya variasi kecil-kecil. Kalau kamu mancing di mancing mania, kamu sekali mancing dapat sepuluh, iya? Sekali mancing satu tarikan ini dapat sepuluh? Tidak. Dapat berapa? Satu. Tapi kalau dengan pukat harimau, sekali jaring ditebar langsung dapat banyak mulai dari yang kecil sampai besar. Tontonan yang kamu dapatkan. Tidak hanya sepuluh tapi ton-tonan, sekali tebar jaring. Dan ini tidak boleh, dilarang, kenapa? Kenapa tidak boleh? Karena bakalnya ikan yang kecil itu kamu tangkap, kalau bakalnya kamu tangkap adakah calon ikan yang baru? Tidak, habis. Sehingga tidak boleh pakai pukat harimau. Pukat harimau itu apa? Kenapa kok pukat harimau? Kok undak pukat kucing? Kenapa kok undak pukat anjing? Harimau itu kan raja, tidak ada yang menguasai. Kalau harimau dapat, semuanya ya dapat sudah. Karena yang paling galak harimau. Kemudian dengan apa yang bisa mematikan ikan dari laut atau sungai? Dengan potas atau racun itu sama saja dengan membuang limbah. Ke mana?

Pemakaian penanda kohesi substitusi berupa pemakaian kata bantu tanya siapa mengacu pada referen manusia. Kata bantu tanya kenapa (terkena apa) mengacu pada referen penyebab. Kata bantu tanya berapa mengacu pada referen jumlah. Kata bantu tanya ke mana mengacu pada referen arah tujuan.

\section{Penanda Kohesi Hiponimi}

Penanda kohesi hiponimi berupa penanda hubungan leksikal dengan menggunakan kata yang maknanya mengacu pada makna kata yang memayunginya. Pemakaian penanda kohesi hiponimi dalam pertanyaan guru terdapat pada data berikut.

(20) Guru : Kenapa? Iya sama, kalau kamu punya hewan-hewan itu, kan kucing pun ada sertifikatnya, golongan kucing yang bulunya buagus itu ada sertifikatnya jadi penangkaran yang ada rejo sewu, ya. Sekarang balik lagi. Kenapa gajah 
bisa masuk ke pemukiman? Kenapa kera masuk sampai ke rumah-rumah penduduk macam-macam sampai jadi korban, kenapa?

Siswa : Makanannya habis.

Guru : Makanannya? He, makanannya apa?

Siswa : Daging

Pada data (20) terdapat pemakaian penanda kohesi berupa pemakaian kata yang mengacu pada referen yang berbeda dengan kata sebelumnya, akan tetapi mengacu pada kelompok yang sama atau memayungi kata yang disebutkan berikutnya. Dengan kata lain, digunakan kata yang menunjukkan hubungan antarproposisi berupa hubungan kelas yang sama, yakni kata hewan-hewan dan kata gajah, kera, dan kucing.

\section{Penanda Kohesi “Konjungsi"}

Konjungtor adalah kata yang berfungsi menghubungkan bagian kalimat dengan bagian yang lain. Pemakaian penanda kohesi dapat juga dilihat dari segi hubungan unsur-unsur kalimat pembangun wacana. Pada pertanyaan guru dalam pembelajaran, pemakaian konjungtor sebagai penanda kohesi terdapat pada data berikut.

(21) Guru : Oke. Misalnya ada yang mau diambil, kemudian dikembangbiakkan di tempat yang bukan tempatnya misalnya Komodo dari mana? Ya, diambil ditaruh dibawa ke taman safari, nah dia di situ ditangkarkan. Dikembangbiakkan di situ, supaya apa?

Siswa : "Tidak punah.”

Guru : Tidak punah. Kemudian dengan mengambil telur penyu. Gitu ya. Penyu itu kalau sekali bertelur bisa sampai tujuh puluh.

Pada data tersebut ditemukan pemakaian penanda kohesi berupa konjungtor "supaya" yang menunjukkan hubungan "tujuan". Di samping konjungtor yang mengungkapkan tujuan, digunakan pula konjungtor yang menentukan hubungan urutan. Hal itu terdapat pada data berikut.

(22) Guru : Oke. Misalnya ada yang mau diambil, kemudian dikembangbiakkan di tempat yang bukan tempatnya misalnya komodo dari mana? Ya, diambil ditaruh dibawa ke taman safari, nah dia di situ ditangkarkan. Dikembangbiakkan di situ, supaya apa? Tidak punah. Kemudian dengan mengambil telur penyu, gitu ya? Penyu itu kalau sekali bertelur bisa sampai tujuh puluh. Penyu itu hidupnya di mana?

Siswa : Di pantai.

Guru : Di pantai atau di laut. Tapi kalau dia bertelur dia akan ke darat. Setelah bertelur banyak ditimbun ditinggal. Biasanya setelah ditinggal ini banyak predator, banyak pemangsa lain yang ngincar ini. La untuk penyelamatan hewan ini dititeni ya. Biasanya ada musim kawinnya. Jadinya musim kawin ada penyu naik kemudian bertelur ditandai. Penyu yang masuk ke laut ini diambil. telur-telurnya ini diambil semuanya ditetaskan di ruang penetasan. Kalau nanti sudah menetas ya, akan dikembalikan lagi ke laut. Soalnya kalau dibiarkan banyak hewan predator. Sekarang saya mau tanya. Ka, Telur enak gak? kamu suka telur?

Siswa : Suka.

Pada fragmen tersebut terdapat pemakaian penanda kohesi berupa konjungtor urutan, yakni kata "kemudian" dan "setelah itu". Konjungtor tersebut digunakan untuk menunjukkan hubungan kegiatan yang berurutan dengan kegiatan sebelumnya. Dengan demikian, terjadi hubungan yang harmonis antara tuturan sebelumnya dengan pertanyaan guru berikutnya.

Penanda kohesi berbentuk konjungtor juga ditemukan pada data berikut.

(23) Guru : Yang putih, itu akan didenda. Kalau tidak didenda, dimasukkan ke kurungan. Kemudian yang menembak juga ada Undang-undangnya. Ada Undangundangnya supaya orang tidak ngawur. Kalau ngawur akhirnya semuanya ditembaki. Akhirnya hanya tinggal cerita. Cerita dan gambarnya saja. Ada museumnya di Bandung. Tapi kamu mungkin gak ke Bandung? Mungkin saja, tapi apa? Biayanya besar. Jadi supaya tidak hanya tinggal cerita, itu tujuannya. Supaya tetep ada ya. Ada pertanyaan?

Siswa : Tidak.

Pada data (23) ditemukan pamakaian penanda kohesi berupa konjungtor yang menunjukkan makna 
hubungan urutan, yakni pemakaian kata "kemudian” dan "akhirnya” yang menunjukkan hubungan makna berurutan. Di samping itu, juga ditemukan pemakaian penanda kohesi berupa konjungtor yang bermakna hubungan pertentangan, yakni pemakaian kata "tetapi" dan penanda hubungan penyimpulan, yakni pemakaian kata "jadi”.

\section{Respon Siswa terhadap Pertanyaan Guru}

Pertanyaan diartikan sebagai tuturan yang dimaksudkan untuk memperoleh tanggapan verbal. Sesuai dengan batasan tersebut, dapat dipastikan bahwa dalam pembelajaran, jika guru menyampaikan pertanyaan, maka siswa akan menjawab pertanyaan guru tersebut. Dengan demikian, jawaban siswa sangat bergantung pada pertanyaan guru.

Hasil analisis data tentang koherensi pertanyaan guru dan pemakaian penanda kohesi dalam pertanyaan guru menunjukkan bahwa dalam pembelajaran, pertanyaan-pertanyaan guru menunjukkan adanya koherensi dengan pernyataan maupun pertanyaan sebelumnya dan bahkan dengan jawaban yang diminta kepada siswa berikutnya. Koherensi tersebut dijalin secara implisit melalui hubungan semantis dan gramatikal, maupun secara eksplisit melalui pemakaian penanda kohesi.

Jenis penanda kohesi yang dominan digunakan guru dalam bertanya berupa penanda kohesi reduplikasi (sebagian maupun utuh) dan subtitusi, terutama berbentuk kata bantu tanya apa, siapa, di mana. Pemakaian kata bantu tanya bagaimana juga digunakan dalam pertanyaan guru, akan tetapi sangat terbatas. Pemakaiannya pun dibantu dengan penjelasan yang mengarahkan pada jawaban yang diminta.

Berdasarkan karakteristik pertanyaan yang disampaikan guru ditinjau dari segi koherensi dan

khususnya pamakaian penanda kohesi dalam bertanya, diketahui bahwa respon siswa terhadap pertanyaan guru cenderung berbentuk jawaban singkat (kalimat pendek), bahkan berupa kalimat elips. Hal itu dapat ditunjukkan pada data berikut.

(24) Guru : Sudah ya kita mulai. Sekarang materi baru setelah kalian UTS. Coba, sebelum ke materi baru keanekaragaman makhluk hidup dan upaya pelestariannya, sekarang keanekaragaman makhluk hidup kemarin yang kamu buat seperti ini (sambil menunjuk ke gambar yang ada di dinding) itu apa saja?
Siswa : Produsen.

Guru : Ada, ada produsen. Terus?

Siswa : Konsumen.

Guru : Ada konsumen. Kemudian ada? Konsumen ada konsumen tingkat satu, dua, tiga, dan seterusnya. Kemudian ada pengurai. Kalau konsumen satu itu apa?

Siswa : Herbivora.

Guru : Golongan konsumen satu? Herbivora yang memanfaatkan langsung atau mendapatkan energi langsung dari produsen. Kalau konsumen dua?

Siswa : Karnivora.

Guru : Golongan predator atau karnivora. Artinya apa? Mendapatkan energi dari konsumen tingkat satu. Sekarang apa yang terjadi kalau konsumen dua atau konsumen dua itu di situ, misalnya, apabila seperti katak, habis diburu? Apa yang terjadi?

Siswa : Belalangnya banyak.

Guru : Belalangnya banyak. Kenapa belalangnya banyak?

Siswa : Tidak ada yang memangsa.

Guru : Tidak ada yang memangsa, sedangkan ularnya mati. Kenapa mati? Karena tidak ada makanan atau (guru dan siswa serentak menjawab). Dek ingat ayo. Nah sekarang, materi sekarang, bagaimana caranya melestarikannya? Bagaimana cara melestarikannya? Itu ada bermacam-macam. Misalnya?

Siswa : Dengan dibudidayakan?

Guru : Dengan dibudidayakan. Kemudian, yang dibudidayakan apanya dulu? Belalangnya? yang dibudidayakan apanya dulu?

Siswa : Ular.

Guru : Ularnya? Tumbuhannya yang kita budidayakan. Kemudian, belalang itu merupakan apa itu?

Siswa : Serangga.

Guru : Serangga. Terus bagaimana dengan serangganya? Dimusnahkan?

Siswa : Tidak.

Guru : Tidak. Jika dimusnahkan ekosistemnya menjadi tidak seimbang. justru kataknya akan mati. Jadi tidak boleh dimusnahkan, kalau dimusnahkan 
ekosistemnya menjadi tidak seimbang. Jadi ada yang dibunuh, dan kemudian ada juga yang hidup. Kalau dibiarkan akan menyebabkan serangga banyak. Sekarang upaya pelestariannya (membuka buku kemudian menulis di papan tulis) MH apa?

Siswa : Makhluk hidup.

Pada data tersebut ditemukan respon siswa terhadap pertanyaan guru berupa jawaban-jawaban pendek, rata-rata berupa satu kata. Hal itu disebabkan oleh bentuk pertanyaan guru yang cenderung magarahkan siswa untuk memberikan jawaban pendek, yakni dengan menggunakan kata bantu tanya "apa”. Kata bantu tanya "Bagaimana" juga digunakan guru dalam bertanya, akan tetapi diikuti dengan pertanyaan yang bersifat mengarahkan, yakni mengarahkan siswa untuk memberikan jawaban singkat.

Paparan pembahasan ini difokuskan pada pembahasan terhadap hasil penelitian sesuai dengan masalah dan tujuan penelitian yang telah ditetapkan. Hasil penelitian menunjukkan bahwa koherensi pertanyaan yang disampaikan guru kepada siswa dalam pembelajaran diwujudkan secara eksplisit melalui penanda kohesi dan secara implisit melalui hubungan semantis. Secara eksplisit, koherensi pertanyaan guru cenderung menggunakan penanda kohesi reduplikasi dan substitusi. Hal itu dapat dipahami karena pemakaian penanda kohesi reduplikasi lebih mudah diterapkan.

Hasil penelitian juga menunjukkan bahwa sesuai dengan karakteristik pertanyaan yang diajukan guru, respon siswa cenderung berupa jawaban singkat yang memerlukan tingkatan berpikir rendah, yakni tingkat pengetahuan atau ingatan. Hal itu tidak sesuai dengan harapan yang tertuang dalam standar proses bahwa sebaiknya guru lebih banyak menggunakan jenis pertanyaan apa, bagaimana, dan mengapa. Jenis pertanyaan tersebut diharapkan akan mampu mengembangkan kompetensi berpikir tingkat tinggi pada siswa.

\section{KESIMPULAN}

Hasil penelitian ini dapat disimpulkan sebagai berikut. (1) Koherensi pertanyaan guru dinyatakan secara eksplisit dan implisit. Koherensi eksplisit dinyatakan menggunakan penanda penghubung formal (penanda kohesi) pengulangan (reduplikasi), substitusi, penanda hubungan unsur kalimat, koreferensi, dan hubungan leksikal, sedangkan koherensi implisit pertanyaan guru dapat dipahami melalui inferensi, kesamaan pengetahuan dunia penutur (guru) dan mitra tutur (siswa), melalui penafsiran lokal (kontekstual), dan implikatur. (2) Penanda kohesi yang digunakan guru meliputi (a) pengulangan utuh dan sebagian, (b) substitusi: pronomina dan demonstratif, (c) hiponimi, dan (d) hubungan leksikal. Berdasarkan koherensi dan pemakaian penanda kohesi dalam pertanyaan guru tersebut, respon siswa cenderung berupa jawaban singkat dan menuntut tingkat berpikir rendah. Hal itu disebabkan oleh jenis pertanyaan guru yang cenderung mengarah pada permintaan informasi secara singkat melalui pemakaian penanda kohesi berupa kata bantu tanya apa dan di mana, yang cenderung menuntut tingkat berpikir rendah untuk menjawabnya.

\section{DAFTAR PUSTAKA}

Alwi, Hasan, dkk. 2003. Tata Bahasa Baku Bahasa Indonesia. Jakarta: Balai Pustaka.

Brown, Gillian and Yule, G. 1983. Discourse Analysis. London: Cambridge University Press.

Canale, M. \& Swain, M. 1981. A Theoretical Framework for Communicative Competence. Washington DC: Teacher of English to Speakers of Other Language.

Eriyanti, R.W. 2014. Retorika dalam Bahasa Guru pada Pembelajaran. Prosiding Seminar Internasional Bahasa, Sastra, dan Pembelajarannya Pengembangan Nilai-Nilai Profetik dalam Kehidupan Berbangsa melalui Bahasa, Sastra, dan Pembelajarannya. Diselenggarakan Program Studi Pendidikan Bahasa dan Sastra Indonesia FKIP UMM, Malang 17-18 November 2015.

Halliday, M.A.K. and Hasan, R. 1976. Cohesion in English. London: Longman.

Hymes, D. 1974. Foundation in SociolinguisticAn Ethnographic Approach. Philadelphia: The University of Pennsylvania Press. Inc.

Ibrahim, A.S. 2001. Pengantar Sosiolinguistik. Malang: Fakultas Sastra UM.

Jumadi. 2005. Representasi Power dalam Wacana Kelas (Kajian Etnografi Komunikasi dan pragmatik di SMA Negeri I Malang). Disertasi tidak Dipublikasikan. Malang: Univ. Negeri Malang.

Moleong, Lexy. 2005. Metodologi Penelitian Kualitatif. Bandung: remaja Rosdakarya. 
Keraf, G. 1985. Diksi dan Gaya Bahasa. Jakarta: PT Gramedia.

Kementrian Pendidikan dan kebudayaan Nasional. 2013. Modul Pelatihan Implementasi Kurikulum 2013. Jakarta: Kemdiknas.

Kementrian Pendidikan dan Kebudayaan Nasional. 2013. Peraturan Menteri Pendidikan dan Kebudayaan nasional Nomor 65 Tahun 2013 tentang Standar Proses Pendidikan Nasional. Jakarta: Kemdiknas.

Leech, G. 1983. Principle of Pragmatik. London and New York: Longman.

Mujianto. 1998. Retorika Wacana Orasi Ilmiah. (Disertasi tidak Dipublikasikan). Malang: IKIP Malang.

Oka, I.G.N. dan Basuki. 1990. Retorika Kiat Bertutur. Malang: Penerbit YA3.

Syafi'ie, I. 1988. Retorika dalam Menulis. Malang: Fakultas Pascasarjana IKIP Malang.

Wahab, A. 1991. Isu-Isu Linguistik-Pengajaran Bahasa dan Sastra. Surabaya: Erlangga University Press. 